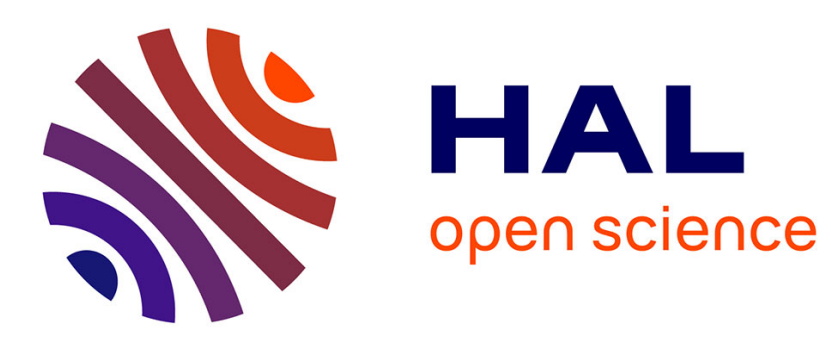

\title{
Electron capture imaging of two-dimensional materials
}

\author{
Alain Dubois, Gabriel Labaigt, Jan Petter Hansen
}

\section{To cite this version:}

Alain Dubois, Gabriel Labaigt, Jan Petter Hansen. Electron capture imaging of two-dimensional materials. Journal of Physics: Conference Series, 2015, 635 (3), pp.032025 10.1088/17426596/635/3/032025. hal-01265946

\section{HAL Id: hal-01265946 \\ https://hal.sorbonne-universite.fr/hal-01265946}

Submitted on 1 Feb 2016

HAL is a multi-disciplinary open access archive for the deposit and dissemination of scientific research documents, whether they are published or not. The documents may come from teaching and research institutions in France or abroad, or from public or private research centers.
L'archive ouverte pluridisciplinaire HAL, est destinée au dépôt et à la diffusion de documents scientifiques de niveau recherche, publiés ou non, émanant des établissements d'enseignement et de recherche français ou étrangers, des laboratoires publics ou privés.

\section{(c)(1)}

Distributed under a Creative Commons Attribution| 4.0 International License 
Electron capture imaging of two-dimensional materials

This content has been downloaded from IOPscience. Please scroll down to see the full text.

2015 J. Phys.: Conf. Ser. 635032025

(http://iopscience.iop.org/1742-6596/635/3/032025)

View the table of contents for this issue, or go to the journal homepage for more

Download details:

IP Address: 134.157.80.136

This content was downloaded on 01/02/2016 at $16: 43$

Please note that terms and conditions apply. 
XXIX International Conference on Photonic, Electronic, and Atomic Collisions (ICPEAC2015) IOP Publishing Journal of Physics: Conference Series 635 (2015) 032025 doi:10.1088/1742-6596/635/3/032025

\title{
Electron capture imaging of two-dimensional materials
}

\author{
Alain Dubois* ${ }^{1}$, Gabriel Labaigt*, and Jan Petter Hansen ${ }^{\dagger 2}$ \\ * Laboratoire de Chimie Physique-Matière et Rayonnement, UPMC-CNRS UMR 7614, F-75005, Paris, France \\ ${ }^{\dagger}$ Department of Physics and Technology, University of Bergen, N-5007, Bergen, Norway
}

\begin{abstract}
Synopsis The principles of an imaging technique for 2D materials are presented. It is based on the measurement of differential cross sections for electron capture induced by impact of keV-proton on such materials. We illustrate these principles for graphene target and demonstrate the selectivity of this technique upon materials, geometries and surface defects through the highly coherent phenomenon giving rise to the imaging pattern.
\end{abstract}

Two-dimensional materials, e.g. graphene, designed with spectacular properties, possess an important potential for applications. Aside their macroscopic features, the present possibility to suspend them on boundaries [1] opens rather new lines of studies based on their quantum properties at the atomic level, such as tunneling, specific reactivity in a molecular environment, ... The dynamics response of graphene to strong and ultrafast perturbations is one of these lines and is still largely unexplored nowadays. Concerning laser field interaction theoretical investigations have predicted strong high harmonics generation and formation of focused beam of relativistic electrons $[2,3]$. Concerning highenergy ion irradiation attention has been focused on defect formation and hardness properties, e.g. $[4,5]$. For low-energy ion-impact a recent investigation [6] simulated images of graphene using the ionization process induced by $30-\mathrm{keV} \mathrm{He}^{+}$impact on single suspended sheet. Based on time-dependent density functional theory a large part of the ultrafast electronic dynamics during the scattering event was ignored.

During the conference, we shall present the principle of a new imaging technique based on electron transfer from the sample to the projectile ion. Our predictions stem from a newly developed approach based on scattering theory state-of-the-art semiclassical non perturbative treatment [7] where the periodicity of the target is taken into account. We shall show that contrasted - atom/site selective - images (cf. Figure 1) can be formed due to coherent mechanisms working on each node of the lattice in a rather narrow domain of impact energies. State-tostate probabilities, energy dependence and geometrical selectivity of the process will be also presented.
A surprising contrast of the images produced by our calculations is observed when comparing to the ion-atom counterpart. A simple and illuminating model will be presented in order to explain the coherent multicenter effect giving rise to this behavior, opening the way to generalize this imaging principle to any periodic twodimensional materials.
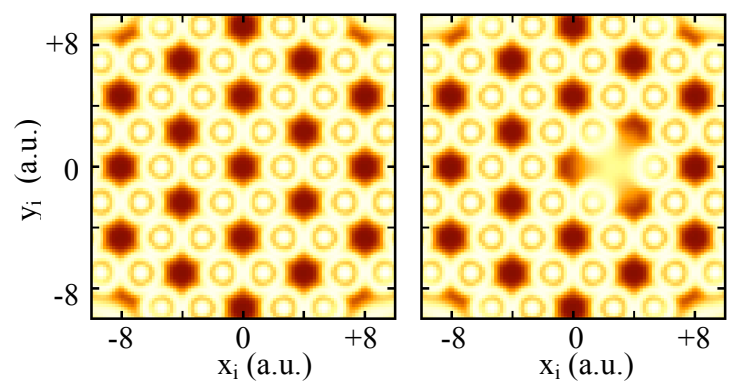

Figure 1. Left: Total electron capture probability as function of impact positions of $\mathrm{H}^{+}$on a semi-infinite graphene surface, perpendicular to the projectile beam. Collision energy is $7.5 \mathrm{keV}$. Right: same as left but with a single vacancy (missing carbon atom in the lattice).

\section{References}

[1] K. Yu et al 2011 J. Phys. Chem. Lett. 2537

[2] S.A. Sørngård, S.I. Simonsen, and J.P. Hansen

2013 Phys. Rev. A 87053803

[3] V.V. Kulagin et al 2009 Phys. Rev. E 80016404

[4] S. Mathew et al 2011 Carbon 491720

[5] G. Compagnini et al 2009 Carbon 473201

[6] H. Zhang, Y. Miyamoto, and A. Rubio 2012

Phys. Rev. Lett. 109265505

[7] G. Labaigt, A. Dubois, and J.P. Hansen 2014

Phys. Rev. B 89245438

\footnotetext{
${ }^{1}$ E-mail: alain.dubois@upmc.fr

${ }^{2}$ E-mail: jan.hansen@uib.no
} 